\title{
Doing and undoing gender in innovation: Femininities and masculinities in innovation processes
}

Lara Pecis

University of Bath

DOI: $10.1177 / 0018726716634445$

\begin{abstract}
Despite the rising interest in the intertwining of individuals, organisations and institutions in innovation research, scant attention has been paid to the ways that their relations produce and reproduce specific gender dynamics throughout the innovation process. Innovation research has been characterised by a gender blindness that conceals the gendered nature of innovation processes. This article draws on the material collected through an ethnographic investigation conducted in two research organisations to illustrate how innovation processes are gendered when specific forms of masculinities and femininities are constructed, enacted and resisted by men and women. This article contributes towards developing a gendered understanding of innovation by introducing the term 'positions of displacement' to signal the fluidity and messiness of doings and undoings of femininities and masculinities through innovation practices.
\end{abstract}

\section{Keywords}

Gender and innovation, masculinities and femininities, doing and undoing gender, positions of displacement, gender in organisations, practising gender, innovation.

\section{Introduction}

Innovation is a long-standing topic in organisation and management studies. Current innovation research focuses on its disruptiveness (Christensen and Bower, 1996), the ways 
that innovation is created through breakthroughs (Bessant, 2008), and the networks that build an infrastructure for innovation (Swan and Scarbrough, 2005). Innovation literature engages with the multiple frames of reference within which the actors involved in innovation operate and how these frames influence not only an organisation's view on innovation but also the different paths it may take in its development (Garud and Gehman, 2012).

Notwithstanding the importance of these aspects, little attention has been paid to how people who work on innovation within a specific frame of reference enact gendering practices that might affect its development. Very rarely are innovation and gender explored together. Innovation literature and research have been characterised by gender blindness (Le Loarne and Gnan, 2015), masking the predominance of masculinities in innovation (Ranga and Etzkowitz, 2010). Recent empirical research (e.g., Andresson et al., 2012; Danilda and Thorslund, 2011; Lindberg, 2007, 2010; Lindberg et al., 2012; Lorentzi, 201; Pettersson and Lindberg, 2013) focuses on how innovation policy texts discursively prioritise men and masculinities. Alsos et al. (2013: 9) highlight the lack of empirical research on organisations that should reveal how innovation is 'fundamentally gendered'. This article fills this knowledge gap by using a doing and undoing gender approach (e.g., Kelan, 2010; Martin, 2003, 2006), which focuses on the performance of gender, to systematically analyse research practices. The following research questions are addressed: How do research practices (re)produce collective norms on femininities and masculinities throughout the innovation process? Which practices signal the challenging of the gender binary system and the resignifying of gender through the marginalisation of the specific acceptance of femininities and masculinities?

In this paper, innovation is understood as a relational process created by different actors who shape both the technologies and their social context (Garud and Karnoe, 2003; Garud et al., 
2013). It accounts for the interactions among networks of people (Garud et al., 2011), constituting innovation at the micro-level.

This study is based on an ethnographic investigation conducted in two research and development $(\mathrm{R} \& D)$ centres - an Italian private non-profit biomedical institute (Biomedicine for Life [BfL]) and the British R\&D division of a multinational IT company (Techie Labs $\mathrm{UK}^{\mathrm{i}}$ ). According to the Organisation for Economic Co-operation and Development's (OECD) Science, Technology and Industry Scoreboard (2011), R\&D is the sector with the highest innovation index. ${ }^{\mathrm{ii}}$ The participants explicitly identify their work practices as creating, developing and implementing new methods and products. During the fieldwork, Valery, the head of one BfL laboratory, says, 'One of the innovations we developed here is the technique of identification of podocytes. It was described in the literature; it existed, but it was based on a different method than the one we developed. I carried out the development'. Alan, a manager at Techie Labs UK, explicitly discusses his work in terms of innovation. He is also responsible for organising 'innovation workshops', involving researchers across different Techie research laboratories.

This paper makes three contributions to the interpretation of innovation as a gendered social practice. First, the paper shows that the people involved in creating innovation - in either a male- or female-dominated R\&D context - do and undo gender in multiple and constantly changing ways. This has the potential to shift scholars' attention from challenging a dominant masculine order in innovation to focusing on the different positions on doing and undoing gender that are held by the women and men who create innovation. Such an approach aligns with the works focusing on the 'fluidity that characterizes the embodied experience of gender', which are widely ignored in the current body of research on gender and innovation (Linstead and Pullen, 2006: 1288). 
Second, this article extends Martin’s (2003, 2006) practising gender and gendering practices framework, specifically her understanding of the undoings of gender. This article introduces the concept of 'positions of displacement', where femininities and masculinities are not aligned in a binary and oppositional order; rather, their practising is multiple and nondichotomous.

Third, this paper's methodological contribution consists of framing the lens for a gender analysis in innovation that is focused on gendering practices of doing and undoing, rather than on dominant discourses within policy texts (e.g., Andersson et al., 2012; Ljunggren et al., 2010; Pettersson, 2007). In other words, the article adds to the knowledge about dominant discourses in innovation policy texts, the exploration of innovation-related practices and how these are embedded into and linked by the actors themselves to specific gendering ones.

This article proceeds as follows. First, it outlines recent advancements in gender and innovation research. It then provides an overview of the theoretical framework underpinning the analysis, that of 'doing gender as a social practice’ (Martin, 2003, 2006). After briefly discussing the methods and data analysis, the article presents the findings in the form of ‘fragments' (excerpts) from individual interview transcripts (see Pullen and Simpson, 2009). The article concludes with some considerations on the challenges encountered, outlining the entanglement of innovation practices and gendering ones, as well as the messiness of the gender order in innovation making.

\section{Finding a space for gender in innovation research}

Van de Ven et al. (1999) find that innovation is characterised by different phases (invention, development and implementation). Similarly, Garud et al. (2013: 776) define innovation as 'the invention, development, and implementation of new ideas'. In each phase, the interactions among people shape the infrastructure that sustains innovation, and they also define the directions to be taken. An innovation process is successful not only for the 
technological capabilities acquired, but primarily for the interconnections among different actors, namely, institutions, organisations, users and their 'prevailing ideas of gender, health, and environment' (Kirsch, 2000: 25, cited in Garud and Gehman, 2012: 984).

Nonetheless, scant attention has been paid to a) the link between people's frameworks contributing to the success of the innovation process - and notions of gender and b) how these notions are enacted and (re)produced in the innovation process. Ranga and Etzkowitz (2010: 1) note that thus far, innovation research has been characterised 'either by gender blindness or male dominance' and that empirical research on the gender dynamics influencing innovation processes is still underdeveloped.

Introducing a gender lens to view innovation allows researchers to capture the shaping and performing of specific notions of gender within an innovation-intensive sector and how these notions become embedded in the frameworks of the people who create innovation. This approach contributes to innovation research by providing a more fine-grained understanding of the relational complexities constituting innovation, as well as their gendered nature. Bridging gender and innovation contributes to the conceptualisation of the doing and undoing of gender by showing the connection between specific forms of masculinities and femininities and other processes, such as that of innovation.

Innovation crosses gender in at least two ways: first, in how people understand who is acknowledged as an innovator and second, in the definitions of what innovation is. Regarding the first way, Alsos et al. (2013) argue that gender blindness in innovation research reflects the invisibility of 'people' in innovation, due to the focus on outcomes, processes and systems. Similarly, Andersson (2012:13) claims that 'the dominating image of innovation and innovators builds on stereotypical notions of gender, promoting men and certain forms of masculinity as the norm'. In other words, 'a man with an idea on how a high-tech product can effect renewal processes in a traditional industry fits better as innovation than an ethnic 
minority woman with an idea on how a process may bring about social justice in society’ (Andersson, 2012: 13). Petterson (2007) suggests that the Swedish strategy policy for technical innovation and industrial development implicitly indicates men as the main actors in natural sciences, technology and mathematics, and women as lacking the required technical skills.

According to this body of literature, women are 'silently excluded in the technological innovation policy which focuses on male-connoted industries and makes female-connoted organisations invisible [...] reinforcing and perpetuating the gender system' (Berglund and Thorslund, 2012: 41). Several authors find that promoting men and certain forms of masculinities as the norm for innovation minimises the role of women and of femininities in the process, reproducing their exclusion at work. Even when women occupy R\&D positions (Poutanen and Kovalainen, 2013), their presence is made absent through different strategies, such as impeding the creation of spaces for their participation and the promotion of their ideas in group discussions or the hijacking of their innovations by some colleagues.

A second research direction involves the analysis of what is understood as 'innovation'. Berglund and Thorslund (2012) find that in the innovation policy text 'Innovative Sweden', a specific construction of masculinity stresses traditional masculine industries as places where innovations emerge (the so-called 'growth areas'). Similarly, Lindberg et al. (2012: 57-58) suggest that gender and innovation are linked in innovation policies when 'the range of sectors being prioritized corresponds to the sex-segregated labour market and when the innovation system concept is mainly linked to two kinds of technology, both related to hegemonic masculinities (physical strength/mechanical and calculating rationality/technological experts)'.

In focusing on how innovation policies promote certain gender categories (e.g., Andersson et al., 2012; Ljunggren et al., 2010; Pettersson, 2007), a number of issues emerge. The first is 
the reproduction of terms such as man/woman, female/male and feminine/masculine as dichotomous 'polarities' (Knights and Kerfoot, 2004: 431). This paper explores how the terms are dynamically constructed through their interplay at work and how they might overlap or be displaced. The second issue concerns the persistent gap in concretely understanding the ways that gender is done and undone (Deutsch, 2007) in organisations. While acknowledging the fundamental impact of these works on bridging gender and innovation, this paper argues for the need for further research on the gendering practices that women and men construct in association with creating innovation. Methodologically, this article contributes to extant gender and innovation studies by shifting from the focus on what is understood as innovation and who is regarded as an innovator at the institutional and policy-making levels to considering the complex, fragmented and subversive ways of doing and undoing femininities and masculinities while innovating.

This paper engages with a long-standing yet evolving tradition of doing gender, specifically its nuance as a gradually relevant and subverting process (Nentwich and Kelan, 2014). The article delineates a framework based on the concepts of doing and undoing gender, which serves as a theoretical lens for a gender analysis in innovation.

\section{Epistemological orientations on doing and undoing gender}

An ethnomethodological view on gender as a relational construct has flourished in the past decades in organisational studies. The attention has progressively focused on how gender is 'accomplished' through interactions (West and Zimmerman, 1987: 129), as a 'product of social doings', away from gender being a self-evident category. Gender has been increasingly conceptualised as a set of practices that help define relations among men and women, as well as their positioning within situated discourses (Gherardi and Poggio, 2001). Based on Garfinkel's (1967) work, West and Zimmerman's (1987) approach focuses on the micropolitical and interactional activities (gestures, body language and speech) at work. For 
example, Gherardi (1994) identifies the two forms of behaviour - ceremonial and remedial ${ }^{\mathrm{iii}}$ - that construct the dominant symbolic order of gender in organisations. A remedial interchange occurs when men change how they present their masculinity to gain acceptance from their female peers, thus devaluing a specific form of masculinity.

Since the 1990s, relevant research has elaborated on Judith Butler's (1988) construct of performativity as the repetition of stylised acts. Whereas West and Zimmerman's (1987) approach emphasises doing gender through interactions, Butler focuses on the ways that discourses contribute to the formation of the subject (Kelan, 2010). For Butler, gender comprises a series of acts that are simultaneously 'intentional and performative' (1988: 522), influencing the creation of the subject. For example, gendering begins even when the child is still in the womb; a girl is created as a social reality through the label 'girl' by the doctor performing an ultrasound. However, such creation is not transient; the child (as a self) needs to respond to such 'girling' by performing the available subject positions. These refer to discursively created positions through which the self (the child), as a holding term, becomes a subject (a girl). These positions are ‘ek-static’ (Harding et al., 2014: 1218), placed outside the self, and it is only through the repetition of available positions that the self (child) becomes a girl.

Research engaging with such an approach has emphasised that 'gender and its performance' (Pullen and Simpson, 2009: 567) are not only relational but also situated culturally and historically (Ashcraft, 2006; Bruni and Gherardi, 2001; Gherardi, 1995; Pullen, 2006). In other words, sets of activities are culturally, historically, discursively and physically available for people to mobilise in specific contexts. Martin (2003: 354) defines these sets of activities as gendering practices, which refer to the 'body of practices [...] available for societal members to invoke or display'. An example would be a man referring to women at work as 'girls' (when their age indicates otherwise). For Martin (2006), this concept denotes both the 
existence of a practice that is available in the institutionalised system of gender relations (gendering practices) and the contextually dependent effects of the use of such a practice (practising gender). Gendering practices and practising gender constitute a 'twin dynamic' (Martin, 2006: 257), the former being words and interpretations, the latter being the more dynamic 'sayings' and 'doings' that constitute gender at work. However, as Butler (2004) points out, there is no pre-existing subject in these doings and sayings, but gendered identities materialise (take form) through a repetition of acts. Wickert and Schaefer (2015: 114) express it simply, 'We become gendered through our acts'.

Doing gender implies that gender is constructed in ubiquitous social interactions, but it can also be deconstructed and undone. Deutsch (2007) points out that an ethnomethodological approach to gender also involves understanding the resistance to gendering practices. However, she notices that the revolutionary power of undoing gender has primarily been used to show the crystallisation of gender relations and the ways that changes feed back into the processes of conformity. Kelan (2010) argues for a significant difference between the ethnomethodological perspective on undoing gender and the poststructuralist one. An ethnomethodological approach focuses on 'the mismatch between sex category and gender' (Kelan, 2010: 190) and how such a mismatch is used to unsettle the female/male sex binary. Ethnomethodologically grounded studies focus more on the persistence of inequalities rather than on questions of change. From this perspective, people undo gender when they perceive it as less relevant to making sense of a situation (Deutsch, 2007; Nentwich and Kelan, 2014). For example, Bruni et al. (2004), Gherardi (1994, 1996) and Gherardi and Poggio (2001) show that a symbolic gender order is enacted or denied in different situations; a collegial slap on the back is one way of making gender less relevant, second-ordered to someone's inclusion into a men’s club. 
A poststructuralist perspective shifts the focus from interactions to the inclusion of the discourses through which gender is undone. Pullen and Knights (2007) note that 'undoing gender' - in a Butlerian way, as subverting gender norms - has both negative and positive connotations. This enriches the complexity of doing gender, where the border between an undoing that makes life unliveable and one that opens up creative opportunities for change (and maybe a newer concept of a more liveable personhood) is blurred. 'I may feel that without some recognizability I cannot live. But I may also feel that the terms by which I am recognized make life unlivable’ (Butler, 2004: 4). For example, Powell et al. (2009) illustrate the collusive manoeuvres that disqualify women engineers' gender, as well as the coping mechanisms that women enact at work, such as 'acting like one of the boys' or accepting discrimination.

Many works in organisational studies have contributed towards a better understanding of gender undoing at work as a subversion of norms (Linstead and Brewis, 2004; Nentwich, 2008; Poggio, 2006), as well as to merging ethnomethodological and poststructuralist epistemological orientations (Bruni et al., 2005; Gherardi and Poggio, 2007). Hall et al. (2007) and Pullen and Simpson (2009) show the mobilisation of different kinds of 'masculinity' and 'femininity', which position men or women as the 'other'. Using the narratives of men taking parental leave, Murgia and Poggio (2009) illustrate some ways of questioning and destabilising dominant gender models. Risman (2009) strongly criticises femininities and masculinities as theoretical constructs. She reminds people of the danger of reductionism in collating femininities as collective norms, even in their multiplicity, with a female sex (and organs). There is the risk of falling into a 'blind intellectual alley' (Risman, 2009: 82) when labelling groups of men as doing a specific form of masculinity or women creating new gender forms as doing new types of femininities. Despite Risman's critique, recent studies using constructs of femininities and masculinities (e.g., Knights and Tullberg, 
2011; Pullen and Simpson, 2009) elucidate the complex interactions and interpretations of the sexes. In line with these works, this paper uses masculinities and femininities as cognitive shortcuts to refer to subject positions that are done, undone and re-done in the complex interactions among people. More specifically, masculine and feminine are understood, not as dispositions but as ‘accomplishments’ (Butler, 1995: 168).

Martin (2003) encourages researchers to focus on how femininities and masculinities are enacted, instead of a general attention to doing gender. In tracing femininities and masculinities - and their multiplicity ${ }^{\text {iv }}$ - the present article theoretically contributes to extending Martin’s (2001, 2006) work on practising gender. It does so by introducing the term 'positions of displacement' to indicate the doings and undoings of femininities and masculinities, which do not produce a neat gender binary order but a complex one in which specific innovation practices can signify several forms of femininities/masculinities.

This paper's analysis rests on the following assumptions. First, it aligns with Nentwick and Kelan's (2014: 130) claim that 'there is no easy way to understand gender but that one must pay attention to how the relevance of the gender binary changes from one situation to another'. Second, in formulating the research questions, analysis and design, this paper follows Kelan and Nentwich's view of gender as ‘an ongoing activity or a "doing” within everyday life' (2009: 139), 'gradually relevant and subverted' (129). The analysis offered in this article focuses on the naturalisation and institutionalisation of the terms of gender - how research practices produce and reproduce collective norms on femininities and masculinities throughout the innovation process. Then, the article traces the instances when the binary system is challenged and how gender is 'resignified' (Butler, 2004: 216) through the marginalisation of the specific acceptance of femininities/masculinities. Third, masculinities and femininities are understood as never fixed nor essential (Kerfoot and Whitehead, 1998). They refer to multiple ways of being, as 'practices of gender signification in a given spatial 
and temporal location', which strengthen the sense of gender validation (Kerfoot and Whitehead, 1998: 440). In other words, masculinities and femininities are 'notoriously changeable' (Butler, 2004: 10), in a constantly shaping relation to each other. Fourth, this article is based on the assumption that innovation is not simply a context for gendering. Innovation is a process that covers several complexities - evolutionary, relational, temporal and cultural (Garud et al., 2013) - posing challenges for its governance. Whereas relational complexity refers to tensions between actors' different frames of reference, and the multiplicity of affordances emerging through their actions (Garud et al., 2013), the article illustrates another dimension of such complexity. Through interactions among actors with different frameworks on innovation, gender as a 'dynamic process' (Martin, 2003: 342) is pervasively practised. This aligns with Acker's (1990: 146) claim that 'gender is not an addition to ongoing processes, conceived as gender neutral. Rather, it is an integral part of those processes, which cannot be properly understood without an analysis of gender'. The present article makes an empirical contribution by showing that gendering and innovating are coupled and intertwined. It not only illustrates that innovation is a fundamentally gendered process but that gendering practices create tensions that become an integral part of the 'relationally complex' (Garud et al., 2013) innovation process. These tensions refer, for example, to the contention between the lack of knowledge sharing associated to a specific form of femininity and the identification of collaboration as a key practice in making innovation.

This article works towards the elision of dichotomous polarities (Knights, 1997). It does so by shifting the focus from the equity between women and men in a gender analysis of innovation (prominent in extant gender and innovation research) to 'gender fluidity' (Linstead and Brewis, 2004: 356) and the relational formation of femininities and masculinities in innovation. 


\section{Studying innovation and gendering in organisational settings}

This qualitative, ethnographic-based study of two research organisations focused on both overt participant observation and semi-structured interviews. As Poggio (2006: 229) notes, techniques such as participant observation or narrative interviews are more suitable 'to grasp the processual and interactive dimension of gendering in its two main aspects: saying and doing'. Observations mixed with ad hoc interviews are better suited for exploring the situated unfolding of processes in situ, in line with the view of Barley and Kunda (2001), who suggest that such a combined approach (versus interviews alone) can better capture work practices.

All forms of enquiry are circumscribed to the researcher's paradigmatic positions, which engrain specific epistemological and ontological assumptions about the world (Chia, 1996). Cunliffe (2003) suggests that the world we seek to study -as ethnographers- and the knowledge we produce are emergent from our interactions with such world. Thus, the gendering processes I recount for in this article are time and space-bound configurations of 'meanings, experiences and identities' (Cunliffe, 2003:994) of participants materializing through our encounter, interpreted based on my taken-for-granted suppositions, actions and linguistic practices.

The choice of the two companies as the observed sites, respectively belonging to the pharmaceutical (BfL) and information technology (Techie) sectors and employing over 80\% women (BfL) and over 80\% men (Techie), allowed taking into account different types of ‘idea generators’ (Petterson and Lindberg, 2013).

\section{Methods}

The method used had two stages. First, from the beginning of May until mid-August 2012, I conducted observations and interviews in BfL on a daily basis, according to the employees' work hours. A pharmaceutical non-profit research centre, BfL develops innovation and research in several biomedical areas, including cardiovascular, kidney and neurological 
diseases and cancers. Overall, BfL employs 900 people, of whom over 60 in the research setting were studied (BfL Alpha). In BfL, I closely observed the members of the Tissue Engineering Unit and interviewed 25 of them, from the laboratory directors to the junior researchers. The organisation was responsible for choosing the participants. The observations generated a 37-page research diary, including field notes, ${ }^{\mathrm{v}}$ together with various documents and videos of project presentations and seminars held in BfL.

At the end of August 2012, I accessed Techie Labs UK, one of the four advanced research laboratories of Techie, an American multinational IT firm. Techie Labs UK employed around 40 people. The team that was observed during the study comprised the researchers in the Security and Cloud Department, specifically working on the 'Defending the Cloud' project to develop an innovative solution for detecting malware. The fieldwork materials consisted of internal documents, 43 handwritten pages of field notes and 17 semi-structured interviews. The interview participants were recruited on the basis of their expressed interest in contributing to this study.

\section{Data analysis}

This study drew on the grounded theory approach in the data reduction process (Gioia et al., 2013; Nag et al., 2007). The datasets were first coded separately, resulting in 73 first-order codes for Techie and 58 for BfL. First codes are developed in proximity to the data (Charmaz, 2006) and describe actions such as accounting, explaining, perceiving and identifying. In the second step, these codes were synthesised into second-order themes, describing patterns of actions. The second-order themes were then combined into aggregate dimensions, identifying macro-areas of processes, such as discourses attributing meaning to creating innovation, experiences in gendered environments, among others. Table 1 presents a summary of the analysis and the aggregate dimensions, second-order themes and first-order codes. 
INSERT TABLE 1 ABOUT HERE

The discussion in this article focuses on the experiences of men and women who work in mainly male- or female-dominated $\mathrm{R} \& \mathrm{D}$, which fall under the aggregate dimension 'experiences in a gendered environment'.

The data is presented in the form of 'fragments' (Pullen and Simpson, 2009), representative of the themes about the experiences in a gendered environment. These excerpts were selected for their 'evocative content' (Martin, 2001: 594) and the gender dynamics educed. The accounts first illustrate how innovation is a gendered social practice and then move towards exploring the ways that femininities/masculinities are done in innovation-oriented settings, by men for women and by women for women. These explain the ways of marking and casting females as a collective subject, constructed in opposition to men. These undoing and resistance of the female collective subject are emphasised in the final section, with fragments showing the binary gender order being dismantled through innovation-oriented practices of collaboration, reinforced through discursive occurrences.

\section{Innovation as a gendered social practice: Unwanted reproductive bodies}

Laura is a molecular biologist who has worked for BfL for over 20 years. Her account is emotionally powerful, elucidating how her decision to become a mother has negatively affected her career. 'I did all kinds of things despite the fact that I was aware of being pregnant. When there was an emergency in the laboratory, I did not step back by saying, "I am pregnant”. When I told him [Laura's boss] this and asked for a decision on a potential permanent contract after my maternity leave, he told me, "You are pregnant; what do you want now?” Being pregnant didn’t cut off half of my brain’. During her first pregnancy, Laura continued working until her due date, and she was reintegrated after three months of maternity leave, with reduced work hours. 'When I came back, they expected me to work 
more, but I was breastfeeding, so at one point, the situation was slightly uncomfortable. They said that since I could not use radioactive substances because I was breastfeeding and [...] always had plenty of milk [...], I should stop breastfeeding and start bottle feeding, so I could work again with radioactivity. So I did it. I was pumping milk when I had it. I had the word idiot printed on my forehead. It was useless’.

In a material sense, Laura’s body cannot accommodate research activities; her reproductive body becomes problematic, disruptive and delegitimised ('You are pregnant; what do you want now?'). In this context, the legitimised employee is gender neutral. Such gender neutrality emerges from both organisations in a twofold way. First, there is a common understanding of the innovative researcher as someone characterised by curiosity, out-of-thebox thinking, who keeps up-to-date with new research trends (expressed in the theme 'having specific qualities as a researcher'). Second, the ideal for an innovative researcher is an individual 'with “no” body' (Bryant and Garnham, 2014: 413). In other words, through a disembodied and gender-neutral ideal, assumptions about gender, for which reproductive bodies are disqualified, are normalised.

Laura nullifies her material body in multiple instances. The first is her decision to continue performing research activities that could endanger the foetus. Second, she separates her practices as a breastfeeding mother from research practices when choosing to stop breastfeeding, rather than requesting different work arrangements. By interrupting breastfeeding and participating in research activities that conflict with her reproductive body, Laura conducts what Gatrell (2011: 159) calls the 'supra-performance’ of pregnant workers. Whereas Gatrell (2011) refers to the organisational strategies and discourses that encourage a woman to be reliable despite her pregnant body, this fragment illustrates how the reproductive woman herself - in response to organisational pressures - enacts a 'supra- 
performance', thus reinforcing and legitimising the organisationally normalised genderneutral idea of an innovator.

Laura's story explains the gendered nature of innovation processes. The following sections delve into the doings and undoings of specific forms of masculinities/femininities.

\section{Doing femininities and masculinities in an innovative organisation: (1) Counting heads}

Alan is a Techie senior researcher based in the USA, managing a research division in Techie Labs UK. During our phone conversation, I mention to Alan, 'This environment is mainly composed of men; there are more men working here'. Alan laughingly replies, 'Is this your observation?' He disagrees, yet the conversation continues. I ask Alan how it is to work in this type of environment. He counters, 'How does it feel for you?' His question comes as a surprise to me; I am a visitor, with no direct experience of working in Techie Labs. Nonetheless, Alan carries on, requesting me to count the number of women and men in Techie Labs UK. He challenges me, 'So that is your perception of the environment? So what kind of ratio would you say is the actual ratio? And what would you prefer? I ask you, because you are a woman'. By laughing and disagreeing with my observation on women being the minority, he is keen in showing that there is no such disparity in numbers. Through his questions, he authorises me to speak for other women (although I was not hired by Techie nor worked in collaboration with Techie employees). Alan locates me in a specific space in which I am the 'non-male'. In other words, he enacts a 'process of othering' (Bruni et al., 2004: 407), which casts the female as the other, the only subject entitled to speak for other women. However, his practising is unreflexive, informed 'by liminal awareness' (Martin, 2003: 345) of his actions, which consequently sets women as a collective subject defined in opposition to men.

Alan's practising gender is shared by his colleagues. For example, George (Techie senior researcher) gives a similar response to my observation: 'Well, I don’t know if that would be 
the case. Have you counted?' George challenges my account, and to demonstrate the inaccuracy of my statement, he names the women and counts their number in his section. Despite his initial doubts, he concludes, '20\% women in a computer science and engineering place is not that bad. I am not quite sure, how would you measure it? What would you compare it with?'

When prompted to increase their gender awareness, Alan and George construct a specific 'subject position' - a repertoire and a position for a person 'within a structure of rights' (Davies and Harré, 1999: 44) - for me as a speaking subject entitled to account for women’s presence and experiences in Techie because 'I am a woman'. These fragments signal that in this male-dominated R\&D context, men - who work closely with women in advancing innovative outputs - tend to be unreflective of women being the minority, to recall their presence by 'counting heads' and to cast them as a collective subject constructed in opposition to men.

\section{Doing femininities and masculinities in an innovative organisation: (2) Hormonal and emotional bodies in innovating}

Whereas Alan and George in Techie cast women as a collective subject in opposition to men by assuming that only a woman is entitled to speak for other women, female researchers in BfL - where women outnumber men - seem to do so reflexively by associating femininity with a competition that does not characterise men. 'In my opinion, working among women is not more difficult, but it is more competitive, whereas when working with the other sex, there is less competition. Men take work in a different way', argues Claire, a newly hired researcher. Claire is locating males and females in a relation where the feminine arena is connoted as competitive and the masculine less so. Femininity is also linked to careerism and the overshadowing of colleagues by 'playing dirty'. Natalie suggests that 'the first [female characteristic] is "getting somewhere", the idea of making a career, getting at a high 
professional level. Women enact certain mechanisms, which may not happen in mixed contexts. Men are more direct. Whereas we [women] tend to be deceptive and create dirty situations with the aim of making it to the top, despite [our] work requiring high levels of collaboration and knowledge exchange’.

The female collective subject, as opposed to men, emerges even more forcefully through differential bodily configurations. Martha (head of the laboratory) suggests that 'there are many menses here [in BfL]. They can be at the same time also. We are very moody and hormonal. This limits our capacity to be always objective. Men are more [fair/objective]. We are more fluctuant. I am not joking. I like working with women because women in general are more precise and methodical [in terms of dexterity]'. In describing research activities, Martha associates a specific type of femininity to the hormonal female body, thus creating a collective subject - the women in an R\&D context, who are moodier, less objective than men and yet more precise and dexterous in their research practices. Based on a sexual dichotomy, women's difference from men is a recurrent narrative in BfL. Here, femininity is linked not only to an erratic behaviour but also to an 'emotional' approach to innovation making, emerging, for example, in the treatment of animals.

The 'binary order' (Murgia and Poggio, 2013: 421) produced and reproduced through specific patterns of discourse by the men in Techie relates to differential workplace experiences of men and women - experiences of numerical dominance in Science, Technology, Engineering and Math (STEM) disciplines. In contrast, the (re)production of a binary order by the women in BfL emerges from the work practices enacted in innovating (e.g., dexterity in handling animals and precision in experiment execution) and hormonal/bodily differences, thus marking women and men as different in their bodies as in innovation practices. 


\section{Undoing femininities and masculinities: Innovation practices and discursive cues of resistance}

Whereas the two fragments cited in the preceding sections delve into the doings of a gender binary order, this section illustrates its undoing. Grace is a postdoctoral researcher who joined BfL a year and a half before my fieldwork took place. She was moved from the Molecular Laboratory (where she first started) to the Cell Biology and Regenerative Medicine Laboratory due to the lack of personnel. Before joining BfL, Grace worked for over seven years as a molecular biologist in a private pharmaceutical company. She describes the new workplace as an arena in which 'there is a knife-fight, a fight that does not allow collaboration, a common objective, working altogether [...] The idea of uniting forces so [as] to reach the common goal does not exist [...] There are borders here; you cannot touch other people's things, there is always a defence 'of the personal'. Martha (head of the Cell Biology Laboratory) cannot know anything about molecular biology because that is Margaret's field, and Martha cannot cross over'. Grace continues by narrating an incident in which she inadvertently crossed the border of competencies among the laboratories.

'For an experiment, there was the need to see if the cells that we were treating were becoming podocytes. There are two ways of doing this [one cellular and the other molecular]. I said to myself, well, I am able to do the molecular so I can do it [...]. Martha called me to her office in the presence of Natalie and another person from the Cell Laboratory, to which I did not yet fully belong. Martha made a big scene in front of these people, shouting [...]. They were upset that I dealt with the molecular because there are certain borders you don't cross within this company. I was breaking the rule’.

Whereas this instance can be interpreted as women's unfriendliness towards female subordinates, it nonetheless shows that (as discussed in the previous section) competition within an R\&D context is understood as a form of femininity. However, Grace's story also 
illustrates how such femininity can be undone and the trouble such undoing causes. In BfL, women established continuity between femininity and competitiveness/withholding knowledge. Grace's use of another laboratory's research practice can be perceived as an undoing that questions the 'naturalness of the gender binary' (Kelan, 2010: 186).

While in this fragment, the undoing of a binary gender order emerges from innovationoriented practices of collaboration, such undoing can also be found in discursive occurrences. Julia, a principal researcher in Techie, describes competitiveness in the organisation as aligned to an American, male-dominated environment: 'I think this is where there could be a gender issue. It is a male-dominated environment here; I think there are [...] 10\% women or maybe less, and I think it is quite competitive. I don't know if it's because of the American influence [since] it is an American company or [...] because it is male dominated, but that seems not to match with me; I don't really like it. It is so competitive, and you need to justify yourself as an individual. [It's] almost a way of putting people too much against each other. You collaborate with people [who] at the same time are your competitors, and they shouldn't be’.

Through this passage, Julia creates a space for resisting the competitive male-dominated environment by framing her experience in terms of a gender issue, by positioning herself as a scientist struggling to match the all-male, Western competitive environment and by suggesting that innovation-oriented practices should envision collaboration instead of competitiveness. This interview situation acts as a locus that enables Julia to reveal her association with masculinity, competitiveness and a Western organisational culture and to elaborate on the trouble it causes her. In other words, the interview dialogue serves to crystallise the ongoing association among competitiveness, masculinity and innovation in the organisation; at the same time, it articulates the struggle and resistance to it. 
In the two organisations, women and men define competition as an aspect of femininity (BfL) or masculinity (Techie). The fragments illustrate that such construction is resisted, both through mobilising research practices that disrupt dominant norms (e.g., Grace’s trespass), and creating an alternative space (the interview dialogue) where the undoing of a dominant masculinity/femininity emerges.

\section{Discussion}

Working inductively from men's and women's accounts, this study answers the first research question (How do practices (re)produce collective norms of femininities/masculinities through innovation processes?) by identifying five ways of doing gender in innovation making. These include men negating women's absence, men positioning women as the legitimate subject to speak of women's experiences, women conflating femininity/ies and competitiveness, women conflating femininity/ies and emotionality, and nullifying the reproductive body. Next, this article addresses the second research question (Which moments signal the challenging of the gender binary and the re-signifying of gender through the marginalisation of the specific acceptance of femininities/masculinities?) by presenting two ways of undoing gender in innovation. These comprise first, the resistance to a dominant femininity through knowledge sharing and second, the creation of a space for resisting masculinities/femininities, which are linked to innovation practices in the interview dialogue. These doings and undoings are respectively summarised, defined and illustrated in Tables 2 and 3.

INSERT TABLES 2 AND 3 ABOUT HERE

In combining an ethnomethodological and poststructuralist interpretation of doing gender, gendering practices in BfL and Techie are recognised as contextually dependent (Martin, 2006) and fluid. From an ethnomethodological viewpoint (Deutsch, 2007), Alan and George 
perform a masculinity that regards the women in their workplace as 'others'; for example, they empower the female interviewer to vocalise women's experiences. At the same time, they undo such masculinity when they think of (and verbalise) the numerical difference between males and females as irrelevant in making sense of their R\&D environment. Gender becomes 'gradually relevant' (Nentwich and Kelan, 2014: 123) when Alan and George are provoked to reflect on the gender diversity in their team and when they acknowledge the women being the minority, as well as the importance of their contribution to research.

On the other hand, a poststructuralist understanding of undoing gender provides information about the instances in which the gender difference is subverted and how alternative performances trouble the dominant gender binary order (Kelan, 2010; Murgia and Poggio, 2013). For example, Grace’s crossing of the imposed borders between different laboratories’ competencies challenges the dominant association of femininity with limited knowledge sharing when performing innovation practices. Similarly, in the interview, Julia creates a space that empowers her resistance to the dominant link among masculinity, competitiveness and innovation practices. In doing so, Grace and Julia create positions of displacement, which question the naturalness of the gender binary in innovation making.

With these positions of displacement, this paper theoretically contributes to the understanding of the complexities of doing and undoing femininities/masculinities in innovation making. 'Positions of displacement' can serve as a term that allows accounting for the multiplicity of gender positions and gendered bodies in the making of innovation, shifting away from a femininity/masculinity binary opposition.

While current gender and innovation research (e.g., Andersson et al., 2012) suggests that the dominating image of innovation and innovators builds on stereotypical notions of men and certain forms of masculinity, this article shows that this is not necessarily the case. Femininities and masculinities are simultaneously enacted in innovation-related activities and 
destabilise the gender order that positions a specific form of masculinity as the norm in innovation. The article shifts from the reproduction of gender binaries in innovation and gender literature to respond to the call for 'developing a practice of multiplicity in gender research' (Linstead and Pullen, 2006: 1307). The fragments presented illustrate that in innovation making, a multiplicity of construction of femininities and masculinities are intertwined, and their binary order does not exclusively promote forms of masculinities in innovation. This case is observed when the women in BfL conflate a form of femininity with competitiveness, mythic emotionality and dexterity in research practices. The BfL researchers construct a form of femininity in opposition to masculinity, where 'men are more objective', and 'men are more direct'. In contrast to current research, this article emphasises that a form of femininity, and not necessarily one of masculinity, is enacted in the innovation-oriented daily practices in BfL. Women and men construct positions of displacement that question the alignment of femininities/masculinities with innovation practices.

Through the concept of positions of displacement, this article questions the primary role of certain forms of masculinities in innovation as marginalising other gendering practices. Instead, it provides an empirical analysis of the ways that femininities/masculinities become dominant and exclusionary in innovation making. Men and women create gender positions that are challenged in two ways. First, they create discursive spaces for resisting the association of femininities/masculinities with innovation making, such as the interview dialogue. Despite not being an 'innovation practice' per se, the interview is another space where the 'binary order' (Murgia and Poggio, 2013), constructed through research practices, crystallises. A second space is the performance of research practices that destabilise gender positions, such as Grace's use of a specific method. This shows that masculinities and femininities can be both displaced and subverted when they are positioned as a dominant gender practice in innovation making. One way of undoing gender is through positions of 
displacement, which create a multiplicity of enacted forms of masculinities and femininities. In my empirical research, this was done by both men and women in either male- or femaledominated contexts, by either challenging or establishing the connection between being a woman and participating in innovation processes. For example, by being present and cooperating in implementing innovation, women disrupt the association between innovation and masculinity.

The gendered frameworks, within which the researchers in BfL and Techie Labs operate, have twofold effects on innovation. First, practices of exclusion of certain bodies and people are pervasively performed. Within the organisational metaphor of an ideal abstract worker, women's emotionality and reproductive bodies are marginalised by the women themselves; some subjects are systematically excluded as legitimate innovation makers. Second, by associating femininity or masculinity with the lack of knowledge sharing that is otherwise fundamental to innovation processes (Swan and Scarbrough, 2005), alternative gender positions, which foster more collaborative dynamics, are delegitimised.

The framework developed in this article enables a gender analysis of innovation that is not based on policy texts but on the concrete practices of women and men in an innovationintensive sector, thus filling the gap in the empirical research on gender and innovation in organisations, as identified by Alsos et al. (2013). Different from the results presented in extant literature (e.g., Petterson, 2007), this study’s findings show that males can regard their female colleagues as equally competent in technical skills. Contrary to Poutanen and Kovalainen's (2013) results, in the two organisations in this present case study, women's presence is not made absent. It is their absence that is negated, but when their presence is acknowledged, their contributions are valued. 


\section{Conclusion}

In writing this paper, I faced several issues when exploring the doings and undoings in innovation-oriented jobs. One such difficulty entailed drawing the line concerning what would constitute innovation - what work practices could be considered innovative. Innovation is a relational process, involving different organisations, stakeholders, ideas and technologies (Van de Ven et al., 1999). Innovation is not singularly located in an organisation, nor is it an individual matter. Not all work practices within an R\&D are innovative per se. However, the very interrelation among people, objects, outcomes and ideas, within the social, economic and legal contexts, enables the creation and implementation of new ideas (Garud and Karnoe, 2003; Garud et al., 2011). Such interrelations and the frameworks within which people operate are not gender neutral. Within this 'relational complexity' (Garud et al., 2013), gendering practices are enacted and affect innovation making. This paper illustrates the multiplicity and complexity of gendering practices in innovation making, the tensions generated within daily research practices by gender doings and undoings, such as the lack of knowledge sharing or the exclusion of specific bodies, and the positions of displacement that are created.

The second challenging aspect involved accounting for the situations in which a gender multiplicity did not lead to an 'orderly gender construction' (Kelan, 2010: 180), to a neat gender 'binary order' (Murgia and Poggio, 2013). In the interviews, the men and the women similarly expressed their discomfort towards a competitive environment, thus creating a space for deconstructing, denaturalising and resisting a hegemonic discourse on competitiveness linked to either a form of masculinity or femininity.

The resistance to and denaturalisation of such competitiveness also took place through their innovation-oriented practices of collaboration and knowledge sharing. In doing so, the men and the women unsettled the association between working in an innovation-oriented sector 
and enacting competitive behaviour, between masculinity and innovativeness and between masculinity and competitive behaviour, thus creating positions of displacement.

Through an analysis of doing and undoing femininities and masculinities (Martin, 2003), this article provides three contributions. First, it highlights that gendering and innovating are coupled and intertwined; innovating is a fundamentally gendered social practice. It proposes gendering as part of the 'relational complexity’ of innovation processes (Garud et al., 2013): innovation participants operate from different (gendered) frameworks on innovation, which create tensions throughout the innovation process, such as the dialectic between collaboration and the demarcation of knowledge boundaries. In doing so, this article shifts the attention away from both a gender-neutral approach to innovation (dominating extant innovation literature) and a gender analysis that, in challenging the masculine order, paradoxically reinforces the gender binary (e.g., Berglund and Thorslund, 2012; Lindberg et al., 2012; Poutanen and Kovalainen, 2013). Instead, the article provides a gendered interpretation of innovation that takes into account the complexities of the movements and interactions between femininities and masculinities. In tracing the fluidity and multiplicity of these domains (Linstead and Pullen, 2006), the article challenges the current views on practising gender as the unsettling and re-organisation of a gender binary, where the undoing of gender is ultimately a crystallisation of such order (Deutsch, 2007). The concept of positions of displacement can better capture the gender doings and undoings that do not produce a neat binary structure but a complex one in which specific innovation practices embed a multiplicity of enacted forms of masculinities and femininities.

This article opens up some opportunities for future research. One potential direction is to delve into organisational discourses that sustain innovation, by asking the question What are the necessary capabilities for performing innovative research practices identified at the organisational level and by people performing innovation? This could inform the workings of 
the reiterative and citational practices (Butler, 1993) that shape the organisational ideal of an innovator, as well as how these citational practices are resisted through the creation of specific positions of displacement.

A second direction for future research could further focus on the corporeal processes emerging through innovation processes, and specifically on how positions of displacement incorporate specific material bodies. If we assume that bodies 'only appear, only endure, only live within the productive constraints of certain highly gendered regulatory schemas.' (Butler, 1993:xi), it is then within these regulatory constraints operating in innovation processes that intelligible bodies are produced, as well as a range of unthinkable and unlivable bodies. This article traced one of such abject bodies -the reproductive body- which supersedes conventional notions of an innovative researcher as an individual with "no" body (Bryant and Garnham, 2014). Research that further investigates how positions of displacement enable the unlivable body to exist and become intelligible is needed.

The article carries some practical implications. It identifies illustrations of gender doings and undoings -sustaining specific gendered frameworks of researchers making innovation- that become dominant or marginalized. In outlining these definitions and their effects on innovation participants, the article marks those areas where more inclusive practices can be implemented. For example, women that conflate femininity with competitiveness, careerism and a 'dirty game', can be prompt to reflect on the effects of such construction of femininity, which is legitimized as part of the identity of an innovator, and to act upon it by envisioning more positive possibilities of this femininity.

Gender and innovation are messy processes; they are corporeal, discursive and practical, but mostly, they are intertwined. This article shows that no innovation making is gender neutral. If scholars think of innovation as a relational process (Van de Ven et al., 2013), they should question it to understand the gendered nature of the relations among researchers who shape 
the path towards innovation, specifically how people working within a framework towards innovating relate to one another in a gendered way.

Research practices in innovation processes are deeply gendered. The stories of the researchers in BfL and Techie illustrate the nuances and complexities of practising and subverting femininities and masculinities in innovation making.

Positions of displacement urge scholars to focus their attention not merely on the construction and dismantling of the dominant forms of masculinity or femininity in innovation processes. Rather, they enable us to grasp the gender complexity created by the movements between these domains and the flexibility of such positions.

\section{References}

Acker J (1990) Hierarchies, jobs, bodies: A theory of gendered organizations. Gender \& Society 4(2): 139-58.

Alsos GA, Ljunggren E and Hytti, U (2013) Gender and innovation: State of the art and a research agenda. International Journal of Gender and Entrepreneurship 5(3): 236-56.

Andersson S, Berglund K, Gunnarsson E and Sundin E (eds) (2012) Promoting Innovation. Policies, Practices and Procedure. Stockholm, VInnoVA-Verket för Innovationssystem/Swedish Governmental Agency for Innovation System.

Ashcraft K (2006) Back to work: Sights/sites of difference in gender and organizational communication studies. In: Dow B, Wood J (eds) The SAGE Handbook of Gender and Communication. London: SAGE, 97-122.

Barley SR and Kunda G (2001) Bringing work back in. Organization Science 12(1): 76-95.

Berglund K and Thorslund J (2012) Innovative policies?: Entrepreneurship and innovation policy from a gender perspective. In: Andresson S, Berglund K, Gunnarsson E, Sundin E 
(eds) Promoting Innovation. Policies, Practices and Procedure. Stockholm, VInnoVAVerket för Innovationssystem/Swedish Governmental Agency for Innovation System, 25-46. Bessant J (2008) Dealing with discontinuous innovation: The European experience. International Journal of Technology Management 42(1): 36-50.

Bruni A and Gherardi S (2001) Omega’s story: The heterogeneous engineering of a gendered professional self. In M. Dent, S. Whitehead (Eds.), Managing professional identities: Knowledge, performativity and the 'new' professional, Routledge, London (2001): 174-198.

Bruni A, Gherardi S and Poggio B (2004) Doing gender, doing entrepreneurship: An ethnographic account of intertwined practices. Gender, Work \& Organization 11(4): 406429.

Bruni A, Gherardi S and Poggio BA (2005) Gender and Entrepreneurship. An Ethnographic Approach. London: Routledge.

Bryant L and Garnham B (2014) The embodiment of women in wine: Gender inequality and gendered inscriptions of the working body in a corporate wine organization. Gender, Work \& Organization 21(5): 411-26.

Butler J (1988) Performative acts and gender constitution: An essay in phenomenology and feminist theory. Theatre Journal 40(4): 519-31.

Butler J (1993) Bodies that Matter: On the Discourse Limits of "Sex". New York and London: Routledge.

Butler J (1995) Melancholy gender-refused identification. Psychoanalytic Dialogues 5(2): 165-80.

Butler J (2004) Undoing Gender. New York: Routledge. 
Charmaz K (2006) Constructing Grounded Theory: A Practical Guide through Qualitative Research. London: Sage.

Chia R (1996) The problem of reflexivity in organizational research: Towards a postmodern science of organization. Organization, 3(1): 31-59.

Christensen CM and Bower JL (1996) Customer power, strategic investment, and the failure of leading firms. Strategic Management Journal 17(3): 197-218.

Cunliffe AL (2003) Reflexive inquiry in organizational research: Questions and possibilities. Human Relations, 56(8): 983-1003.

Danilda I and Thorslund JG (eds) (2011) Innovation and Gender. Stockholm, VInnoVAVerket för Innovationssystem/Swedish Governmental Agency for Innovation System.

Davies B and Harré R (1999) Positioning: The discursive production of selves. Journal for the Theory of Social Behaviour 20(1): 43-63.

Deutsch FM (2007) Undoing gender. Gender \& Society 21(1): 106-27.

Garfinkel H (1967) Studies in Ethnomethodology. Englewood Cliffs, NJ: Prentice-Hall.

Garud R and Gehman J (2012) Metatheoretical perspectives on sustainability journeys: Evolutionary, relational and durational. Research Policy 41(6): 980-95.

Garud R, Gehman J and Kumaraswamy A (2011) Complexity arrangements for sustained innovation: Lessons from 3M Corporation. Organization Studies 32(6): 737-67.

Garud R and Karnøe P (2003) Bricolage versus breakthrough: Distributed and embedded agency in technology entrepreneurship. Research Policy 32(2): 277-300.

Garud R, Tuertscher P and Van de Ven AH (2013) Perspectives on innovation processes. The Academy of Management Annals 7: 775-819. 
Gatrell C (2011) Policy and the pregnant body at work: Strategies of secrecy, silence and supra-performance. Gender, Work \& Organization 18(2): 158-81.

Gherardi S (1994) The gender we think, the gender we do in our everyday organizational lives. Human Relations 47(6): 591-610.

Gherardi S (1995) Gender, Symbolism and Organizational Cultures. London: Sage.

Gherardi S and Poggio B (2001) Creating and recreating gender order in organizations. Journal of World Business 36(3): 245-59.

Gherardi S and Poggio B (2007) Gendertelling in Organizations: Narratives from Maledominated Environments. Copenhagen: Copenhagen Business School Press.

Gioia DA, Corley KG and Hamilton AL (2013) Seeking qualitative rigor in inductive research notes on the Gioia methodology. Organizational Research Methods 16(1): 15-31.

Hall A, Hockey J and Robinson V (2007) Occupational cultures and the embodiment of masculinity: Hairdressing, estate agency and firefighting. Gender, Work \& Organization 14(6): 534-51.

Harding N, Lee H and Ford J (2014) Who is “the middle manager”? Human Relations 67(10): 1213-37.

Kelan EK (2010) Gender logic and (un)doing gender at work. Gender, Work and Organization 17(2): 174-94.

Kelan EK and Nentwich JC (2009) The value of seeing gender as a 'doing'. In: Özbilgin MF (ed) Equality, Diversity and Inclusion at Work: A Research Companion, Cheltenham: Edward Eldgar Publishing, 136-41.

Kerfoot D and Whitehead S (1998) “Boys own” stuff: Masculinity and the management of further education. The Sociological Review 46(3): 436-57. 
Kirsch DA (2000) The Electric Vehicle and the Burden of History. New Brunswick, NJ: Rutgers University Press.

Knights D (1997) Organization theory in the age of deconstruction: Dualism, gender and postmodernism revisited. Organization Studies 18(1): 1-19.

Knights D and Kerfoot D (2004) Between representations and subjectivity: Gender binaries and the politics of organizational transformation. Gender Work \& Organization 11(4): 43054.

Knights D and Tullberg M (2011) Managing masculinity/mismanaging the corporation. Organization 19(4): 385-404.

Le Loarne S and Gnan L (2015) Introduction to the special issue: Is innovation gendered? International Journal of Entrepreneurship and Small Business 24(1): 1-3.

Lindberg M (2007) Deconstructing gender and innovation-four regional networks challenging Sweden's innovation policy. Paper presented at the conference Past, Present and Future in Umeå, Sweden, June 14-17.

Lindberg M (2010) Doing gender in Sweden's innovation policy when transforming academic theory into regional practice. Paper presented at, Madrid, Spain, October 20-22.

Lindberg M, Danilda I and Torstensson BM (2012) Women resource centres - a creative knowledge environment of quadruple helix. Journal of the Knowledge Economy 3(1): 36-52.

Linstead A and Brewis J (2004) Editorial: Beyond boundaries: Towards fluidity in theorizing and practice. Gender, Work \& Organization 11(4): 355-62.

Linstead S and Pullen A (2006) Gender as multiplicity: Desire, displacement, difference and dispersion. Human Relations 59(9): 1287-310. 
Ljunggren E, Alsos G, Amble N, Ervik R, Kvidal T and Wiik R (2010) Gender and Innovation. Learning from Regional VRI-projects. NF-report, Bodø, Nordlandsforskning, 66112.

Lorentzi U (2011) Gender Across the Board. Gender Perspective on Innovation and Equality. Stockholm, VInnoVA-Verket för Innovationssystem/Swedish Governmental Agency for Innovation System.

Martin P (2001) 'Mobilizing masculinities': Women’s experiences of men at work. Organization 8(4): 587-618.

Martin PY (2003) “Said and done” versus “saying and doing” gendering practices, practicing gender at work. Gender \& Society 17(3): 342-66.

Martin PY (2006) Practising gender at work: Further thoughts on reflexivity. Gender, Work \& Organization 13(3): 254-76.

Murgia A and Poggio B (2009) Challenging hegemonic masculinities: Men’s stories on gender culture in organizations. Organization 16(3): 407-23.

Murgia A and Poggio B (2013) Fathers' stories of resistance and hegemony in organizational cultures. Gender, Work \& Organization 20(4): 413-24.

Nag R, Corley KG and Gioia DA (2007) The intersection of organizational identity, knowledge, and practice: Attempting strategic change via knowledge grafting. Academy of Management Journal 50(4): 821-47.

Nentwich J (2008) New fathers and mothers as gender troublemakers? Exploring discursive constructions of heterosexual parenthood and their subversive potential. Feminism \& Psychology 18(2): 207-30. 
Nentwich J and Kelan E (2014) Towards a topology of “doing gender”: An analysis of empirical research and its challenges. Gender, Work and Organization 21(2): 121-34.

Organisation for Economic Co-operation and Development (OECD) (2011) Innovative Sectors. In OECD Science, Technology and Industry Scoreboard 2011, OECD Publishing. Available at: http://dx.doi.org/10.1787/sti_scoreboard-2011-66-en

Pettersson K (2007) Men and Male as the Norm? A Gender Perspective on Innovation Policies in Denmark, Finland and Sweden. Stockholm, Nordregio.

Pettersson K and Lindberg M (2013) Paradoxical spaces of feminist resistance: Mapping the margin to the masculinist innovation discourse. International Journal of Gender and Entrepreneurship 5(3): 323-41.

Poggio B (2006) Editorial: Outline of a theory of gender practices. Gender, Work \& Organization 13(3): 225-33.

Poutanen S and Kovalainen A (2013) Gendering innovation process in an industrial plant. Revisiting tokenism, gender and innovation. International Journal of Gender and Entrepreneurship 5(3): 257-74.

Powell A, Bagilhole B and Dainty A (2009) How women engineers do and undo gender: Consequences for gender equality. Gender, Work \& Organization 16(4): 411-28.

Pullen A (2006) Gendering the research self: Social practice and corporeal multiplicity in the writing of organizational research. Gender, Work and Organization 13(3): 277-98.

Pullen A and Knights D (2007) Editorial: Undoing gender: Organizing and disorganizing performance. Gender Work \& Organization 14(6): 505-11.

Pullen A and Simpson R (2009) Managing difference in feminized work: Men, otherness and social practice. Human Relations 62(4): 561-87. 
Ranga M and Etzkowitz H (2010) Athena in the world of Techne: The gender dimension of technology, innovation and entrepreneurship. Journal of Technology Management \& Innovation 5(1): 1-12.

Risman BJ (2009) From doing to undoing: Gender as we know it. Gender and Society 23(1): 81-84.

Swan J and Scarbrough H (2005) The politics of networked innovation. Human Relations 58(7): 913-43.

Van de Ven AH, Polley DE, Garud R and Venkataraman S (1999) The Innovation Journey.

Oxford: Oxford University Press.

West C and Zimmerman DH (1987) Doing gender. Gender \& Society 1(2): 125-51.

Wickert C and Schaefer SM (2015) Towards a progressive understanding of performativity in critical management studies. Human Relations, 68(1): 107-130.

Table 1. Selected aspects of the data analysis

\begin{tabular}{|c|c|c|}
\hline First-order codes & Second-order themes & $\begin{array}{l}\text { Aggregate } \\
\text { dimensions }\end{array}$ \\
\hline $\begin{array}{l}\text { Playing around the Forensic Virtual } \\
\text { Machine and Gauss. }\end{array}$ & $\begin{array}{l}\text { Attributing playfulness to innovation } \\
\text { practices }\end{array}$ & \multirow{2}{*}{$\begin{array}{l}\text { Discourses attributing } \\
\text { meaning to doing } \\
\text { innovation }\end{array}$} \\
\hline $\begin{array}{l}\text { I love my job. } \\
\text { What motivates me to work. } \\
\text { Passion is the key driver in my work. }\end{array}$ & Enjoying innovation research & \\
\hline $\begin{array}{l}\text { I'm a researcher, and I do this type of job. } \\
\text { Being a researcher is something special. } \\
\text { Identity defined as related to work practices } \\
\text { Not being a researcher. } \\
\text { What research entails and how it should be } \\
\text { done. } \\
\text { Stereotype of computer scientist. } \\
\text { Feeling the need to temporally frame the } \\
\text { job experience. }\end{array}$ & Meaningfulness of being a researcher & \multirow[t]{2}{*}{$\begin{array}{l}\text { Discourses attributing } \\
\text { meaning to } \\
\text { researcher's identity }\end{array}$} \\
\hline $\begin{array}{l}\text { Curiosity. } \\
\text { Out-of-the-box thinking. } \\
\text { It's crucial to be up to date and learn new } \\
\text { things. }\end{array}$ & Having specific qualities as a researcher & \\
\hline $\begin{array}{l}\text { Women are more precise, and they also } \\
\text { accept low-paid and unstable jobs. }\end{array}$ & Discourses on gender differences at work & \multirow{2}{*}{$\begin{array}{l}\text { Discourses creating } \\
\text { gender differences }\end{array}$} \\
\hline $\begin{array}{l}\text { Having [a] family or children [conflicts] } \\
\text { with this work. }\end{array}$ & $\begin{array}{l}\text { Gender disadvantages at work and } \\
\text { impact on career prospects }\end{array}$ & \\
\hline
\end{tabular}




\begin{tabular}{|c|c|c|}
\hline Being pregnant is a disadvantage. & & \\
\hline $\begin{array}{l}\text { Women don't enter the profession of IT } \\
\text { very much. It starts [at the] early stages [in] } \\
\text { school. }\end{array}$ & $\begin{array}{l}\text { Exploring the difficulties of having } \\
\text { women in research positions }\end{array}$ & \multirow{4}{*}{$\begin{array}{l}\text { Experiences in } \\
\text { gendered } \\
\text { environments }\end{array}$} \\
\hline $\begin{array}{l}\text { Sometimes, it's hard to have your voice } \\
\text { heard, as a woman in IT. }\end{array}$ & $\begin{array}{l}\text { Difficulties in group acceptance and } \\
\text { effects on own performance }\end{array}$ & \\
\hline I would prefer a more mixed environment. & $\begin{array}{l}\text { Impact of gender-dominated } \\
\text { environment on workplace satisfaction }\end{array}$ & \\
\hline $\begin{array}{l}\text { Maternity leave meant a loss in [the] } \\
\text { number of researchers for the lab. }\end{array}$ & $\begin{array}{l}\text { Impact of gender-related aspects on } \\
\text { research }\end{array}$ & \\
\hline $\begin{array}{l}\text { We have time for blue-sky research, but it's } \\
\text { hard to conciliate its time and [the] time for } \\
\text { ongoing research. }\end{array}$ & $\begin{array}{l}\text { Time for blue-sky research and reality of } \\
\text { work life }\end{array}$ & \multirow{3}{*}{ Managing time } \\
\hline $\begin{array}{l}\text { I find it hard to keep things going, [to] } \\
\text { conciliate family and work. } \\
\text { It's hard to balance work and private life. }\end{array}$ & $\begin{array}{l}\text { Struggling with managing family and } \\
\text { work }\end{array}$ & \\
\hline $\begin{array}{l}\text { I work all the time: no [free] weekends, no } \\
\text { evenings. }\end{array}$ & Time for work and time for social life & \\
\hline
\end{tabular}

Table 2. Definitions and illustrations of gender doings in innovation making Men making gender irrelevant

Definition: When men non-reflexively deny the absence of women in a male-dominated workplace, they fail to recognise gender diversity as an issue in the workplace.

George and Alan mask the women's numerical minority by initially failing to acknowledge that women researchers comprise a small percentage of the laboratories' workforce.

Effect: By making women's absence invisible, men frame gender as an aspect of daily practices that is irrelevant to the innovation process.

\section{Men marking women as the 'other'}

Definition: When men position women as the non-male and as the legitimate subject to speak of other women's experiences, they create a gender position for a woman to perform.

Alan casts the female interviewer as the entitled subject to speak for women as she is a 'woman'. George delegates to the female interviewer the role of accounting for the desired male/female ratio, where the terms male and female are positioned in a dialectic and exclusionary order.

Effect: Women are thought of as experiencing the work environment in a different way than men.

\section{Women conflating femininity/ies and competitiveness}

Definition: This is the case when women define themselves as female researchers who demonstrate competitive behaviour and outperform their colleagues to reach their desired career goals. 
Claire, Natalie and Penelope refer to women's behaviour as a way of 'getting somewhere' and being competitive, in opposition to men's less competitive behaviour.

Effects: Women conflate femininity with the negative terms of competitiveness, careerism and a dirty game. They also define such femininity as opposite to men's cooperative and more honest behaviour.

\section{Women conflating femininity/ies and emotionality}

Definition: Women define themselves as emotional and less objective than men in doing research, and they link such emotionality to their hormonal body.

Martha collates the female-sexed body with emotionality and hormonal mood swings. Penelope and Martha define a woman in opposition to an ideal of a man who is more objective and direct.

Effects: Women collate femininity with being emotional and moody. This type of femininity is constructed in opposition to a specific form of masculinity, thus recreating a binary in the relations between men and women.

\section{Nullifying the reproductive body}

Definition: When the reproductive body disrupts work practices, women rank it second to research practices. In doing so, they make such a reproductive body invisible in innovation development.

At the same time, the organisation delegitimises such a body by expecting the women's presence at work and refusing their career advancement request.

Pregnancy is perceived as a 'problem' for innovation practices by women in BfL. Laura's interruption of specific work practices is blamed on her, and her efforts in balancing her reproductive body with work culminate in a situation of physical and emotional discomfort. Laura nullifies her material body in multiple instances, such as when interrupting breastfeeding to be able to perform specific research activities.

Effects: A disembodied and gender-neutral ideal of a researcher developing innovations is a shared narrative. The normalisation of reproductive bodies as disqualified bodies marks them as problematic sites of control and exclusion.

Table 3. Definitions and illustrations of gender undoings in innovation making

\section{Resisting a dominant femininity through innovation-related practices}

Definition: This situation occurs when women resist the common practice of not sharing domain-specific knowledge by crossing the borders of competencies.

For example, Grace's trespass of imposed borders among the competencies of the different laboratories challenges the dominant norm that associates femininity with a protective behaviour towards knowledge.

Effect: Women enact the behaviour that contrasts with the dominant gendered norms, for 
which they are sanctioned.

Creating resistance through the interview situation

Definition: The interview situation is taken as the occasion to vocalise the discomfort with and misalignment to a dominant symbolic order.

Through the interview dialogue, Julia creates an alternative space, empowering her to express her uneasiness with the dominant axis of masculinity and competitiveness.

Effects: A form of resistance is enacted not only in innovation-oriented work practices but also through discourse.

\footnotetext{
${ }^{\mathrm{i}}$ All names of companies and people used in the article are pseudonymous.

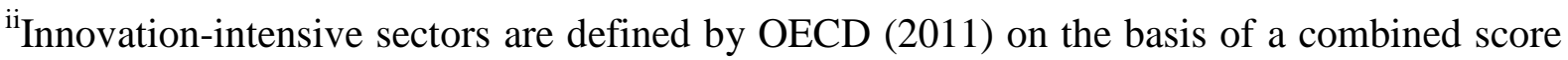
calculated on the following dimensions: product and process innovations, organisation and market innovations, intellectual property rights and innovation-related expenditures.

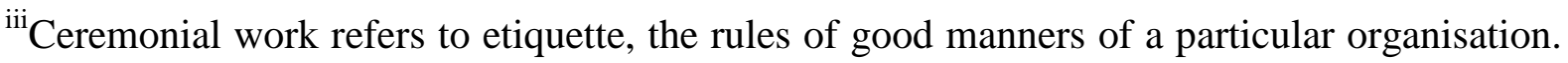

Remedial work involves repairing the established gender order in the organisation (Gherardi,
} 1994).

ivThis is a type of multiplicity that 'does not mean a multiplicity of singularities, of ones, a repetition of the self-same, but a genuine proliferation of processes that are neither ones nor twos’ (Linstead and Pullen, 2006: 1302).

${ }^{\vee}$ The field notes diary constituted 21,089 words, with 91,572 characters (excluding spaces). 